Sri Lankan J. Biol. 2021, 6 (1): 3 - 14

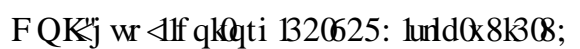

KUSUMRIFIGRUT0000-0002-0882-7147

Invited Review

Open Access

\title{
Insect vectors of human viral diseases: Can they transmit COVID-19?
}

\author{
Dangalle, C.D. ${ }^{1 *}$ \\ ${ }^{1}$ Department of Zoology and Environment Sciences, Faculty of Science, University of Colombo, Colombo 03, Sri Lanka.
}

\begin{abstract}
Many insects are naturally infected by a wide range of viruses and transmit viral diseases that cause significant morbidity and mortality to humans. Amongst insects, mosquitoes are the prominent vectors of viral diseases of which the genus Aedes is the most relevant species regarding disease transmission to humans. Mosquitoes mainly transmit the viruses of family Flaviviridae and the mosquito-borne Flavivirus diseases are the most serious and widespread. Many diseases have been caused by Flaviviruses of which Dengue viral infection and Japanese encephalitis are prominent in countries of the Asian region. Apart from the viruses of family Flaviviridae, mosquitoes also transmit viruses of families Togaviridae and Bunyaviridae, which however have caused disease outbreaks to a lesser extent than the Flaviviridae viruses. Insects other than mosquitoes transmit viral diseases to a lesser extent. Sand fly species of order Diptera transmits viruses of family Bunyaviridae, which causes Sand fly fever mainly in the countries of Europe and Africa. Insects such as cockroaches and fly species are also capable of causing viral diseases to humans, which however is by mechanical transmission, rather than the biological transmission evident in mosquitoes. Covid-19 is transmitted by a RNA virus of the family Coronaviridae, genus Coronavirus. There have been no reports of Covid-19 transmission by blood-sucking insects such as mosquitoes or any other such insects. However, the mechanical transmission of the virus is plausible by body parts of insects contacted with contaminated surfaces. The new coronavirus is mainly transmitted by respiratory droplets that are suspended in the air via breathing, coughing or sneezing of the infected persons. However, the virus has been detected in the feces of confirmed patients and insects in contact with or feeding on fecal surfaces may play a role in Covid-19 transmission. The coronavirus that is now threatening the world is constantly changing and subtly different from the one that first emerged in China. Everyday learning of the coronavirus and its transmission has refined our knowledge on combating it, and the role of insects in Covid-19 transmission cannot be entirely ruled out.
\end{abstract}

Received: 05 Oct 2020

Accepted: 09 Nov 2020

Key words:

Insect vectors

Human viral diseases

Covid-19

*Corresponding author: cddangalle@zoology.cmb.ac.lk

Tel: 0112503399

\section{Introduction}

Insects are carriers of diseases to humans, other animals and plants. Centuries ago, they have been suggested as being possibly entailed in the spread of disease, especially with the outbreak of war (MacGregor, 1918). In 1577 Mercurialis, an Italian physician, suggested that plague, which was then ravaging Europe, was spread by flies feeding upon the diseased and dead, and later depositing fecal matter on food consumed by healthy persons (MacGregor, 1918). The connection between insects and diseases such as Yellow fever, Malaria, Anthrax, Filaria were also established a long time ago (MacGregor, 1918). The Dengue fever, whose global incidence has grown in recent decades was named as breakbone fever at the time and was stated as an insect-borne disease of unknown origin. Sandflies and mosquitoes were named as potential vectors, but the mosquito vectors were identified as Culex fatigans and Stegomyia fasciata (MacGregor, 1918). In 1937, Cook stated of 135 species of insects as vectors of viral diseases in plants. Species of aphids (causing "curl” disease to potatoes, Bermuda Lily disease) and leafhoppers (causing "Dwarf of Rice" disease in Japan, curly top disease of sugar beet in America) were identified as some of the important plant disease vectors (Cook, 1937). 
Today we are aware that insects are very common vectors of disease and transmit viral, bacterial and protozoan pathogens via their bite, or via their feces. The diseases can be asymptomatic to fatal and are commonly grouped as invasive neurological diseases, hemorrhagic fever and systemic febrile illness (Dehghani \& Kassiri, 2020). Viruses transmitted by insects cause diseases that are important world-wide, and result significant morbidity and mortality in humans. However, the literature on the subject is scattered and rarely has been assembled into a single source. The present review attempts to address some key points on the subject regarding human viral diseases transmitted by insects, and the global distribution and symptoms of these diseases, virus types responsible for the diseases and species of the insect vectors are considered. Further, the possibility of insects in transmitting the severe acute respiratory syndrome coronavirus 2 (SARS$\mathrm{CoV}-2$ ), the virus that causes coronavirus disease (COVID-19) is discussed.

\section{Mosquitoes as vectors of human viral diseases}

Amongst insects, mosquitoes are the prominent vectors of viral diseases as 3,500 species are found widely spread worldwide. These species belong to 112 genera of which four genera are repeatedly linked with disease transmission to humans in the tropics and in cooler climates: Aedes, Anopheles, Culex, and Ochlerotatus. The genus Aedes is the most relevant species regarding disease transmission due to their adaptability to urban life and high susceptibility to emerging and reemerging arboviruses (Monteiro et al., 2019).

Although numerous viral diseases are transmitted by mosquitoes, four have caused the most human suffering over the centuries and are continuing today. These are the viral diseases yellow fever, dengue, chikungunya and Zika fever (Powell, 2018). Dengue is associated with human epidemic diseases in urban areas and yellow fever is found in rural areas (Sarwar, 2016). Africa is clearly the ancestral home of yellow fever, chikungunya and Zika viral fever, and likely the dengue viral fever. Several species of mosquitoes, primarily in the genus Aedes, have been transmitting the viruses of these diseases among African primates for millennia allowing for coadaptation among viruses, mosquitoes and primates. One African primate (human) and one African Aedes mosquito (Aedes aegypti) have escaped Africa and spread around the world making it likely that when the next diseasecausing virus comes out of Africa, Aedes aegypti will be the major vector to humans (Powell, 2018).
When considering the viral pathogens of the diseases transmitted by mosquitoes, most viruses are of the families Flaviviridae and Togaviridae (Table 1). The family Flaviviridae consists of at least 68 viruses and is divided into four genera: Flavivirus, Pestivirus, Pegivirus and Hepacivirus (Ludwig \& Iacono-Connors, 1993; Salas-Benito \& De Nova-Ocampo, 2015). The Flavivirus genus consists of 53 virus species (Huhtamo et al., 2009), and is divided into four categories as mosquitoborne, tick-borne, no known vector and insectspecific viruses (Salas-Benito \& De Nova-Ocampo, 2015). The mosquito-borne Flavivirus diseases are emerging as the cause of some of the most serious and widespread arthropod-borne viral diseases in the world and have caused large outbreaks in many countries (Table 1). Currently there are 39 defined species belonging to the mosquito-borne viruses of the genus Flavivirus, and are found in all continents except Antarctica. Some such as the West Nile virus have an extremely wide spread distribution, while others such as the Murray Valley encephalitis virus, Israel turkey meningoencephalomyelitis virus, Ilheus virus are restricted to endemic areas (Weissenbock et al., 2010). Mosquito vectors of the genera Aedes, Anopheles, Mansonia, Culex, Haemogogus and Armigeres are responsible for transmitting Flaviviral diseases which are mainly characterized by high fever and headaches (Table 1). The genera Aedes, Mansonia, Culex, Haemogogus and Armigeres belongs to the subfamily Culicinae which is the largest subfamily of mosquitoes with 2500 species. Aedes is the largest genus comprising of about 1000 species, and Aedes aegypti, Ae. albopictus, Ae. vittatus, Ae. scutellaris, Ae. pseudoscutellaris, Ae. polynesiensis, Ae. bromeliae, and Ae. africanus are the most important vectors from a medical point of view. Aedes aegypti and Ae. albopictus are the most widespread and important vectors and transmit a wide variety of viruses belonging to three families: the Flaviviridae with the genus Flavivirus, Bunyaviridae comprising the genera Bunyavirus and Phlebovirus and Togaviridae comprising the genus Alphavirus (Das et al., 2018). The Togaviridae viral diseases transmitted by mosquitoes are mostly characterized by rashes and joint pains and are more restricted in distribution. These diseases such as Chikungunya fever, Pogosta disease, Mayaro fever and Barmah Forest Virus disease are transmitted by mosquitoes of the genera Aedes, Culex, Haemogogus, Anopheles, Mansonia, Psorophora and Sabethes and have caused outbreaks to a lesser extent (Table 1). The family Togaviridae consists of the genus Alphavirus with more than 30 species which are mosquito-borne and transmitted between mosquito vectors and vertebrate hosts (Chen et al., 2018). 


\section{Other insect vectors of human viral diseases}

Insects other than mosquitoes transmit viral diseases to a lesser extent. In 1965, Greenberg stated that flies harbor over 100 different species of pathogenic organisms and transmits bacterial diseases and infections by parasites. According to Greenberg (1965) flies also transmit viral diseases such as poliomyelitis, coxsackie virus infection and hepatitis, a fact which has also been stated by Lindsay \& Scudder (1955). However, reports of the isolation of viruses from flies are rare and their role in disease transmission are mostly circumstantial. Most viruses carried by flies are of veterinary importance such as the Senecavirus $A$ whose natural hosts are pigs and cows, the porcine reproductive and respiratory syndrome virus which causes diseases to pigs, and Avian influenza virus and Newcastle disease virus that affects birds (Khamesipour et al., 2018).

Dutto et al. (2016) reports the role of several insects in spreading the Ebolavirus which causes a severe disease in humans. Periplaneta americana (Blattaria, Blattidae), Messor capensis (Hymenoptera, Formicidae), Homoptera and Ephemeroptera have been identified as possible natural Ebolavirus reservoirs and their transmission of the virus from bats to humans needs to be established by further studies. However, it has been demonstrated that there is low potential for the mechanical transmission of Ebolavirus via houseflies (Haddow et al., 2017). Further, houseflies are not considered as a major factor in the dissemination of poliovirus and any role played by them in disease transmission has considered to be incidental (Cirillo, 2016).

Another group of tiny flies capable of causing parasitic, bacterial and viral diseases to humans are Sandflies of order Diptera, family Psychodidae (Ayhan \& Charrel, 2018). Of the 800 sand fly species distributed in the world, at least 98 are proven vectors of micro-organisms and transmit a number of viruses that cause sandfly fever, Toscana virus infection and Adria virus infection. These infections are caused by the viruses of genus Phlebovirus, family Bunyaviridae and are characterized by clinical symptoms such as fever, headache, malaise, photophobia, myalgia and retroorbital pain (Ayhan \& Charrel, 2018) (Table 2).The family Bunyaviridae comprises of more than 350 viruses and is divided into five genera, Orthobunyavirus, Nairovirus, Phlebovirus, Hantavirus and Tospovirus with additional unclassified viruses. Viruses within the Orthobunyavirus, Nairovirus, and Phlebovirus genera are transmitted by hematophagous arthropods, whereas Hantaviruses are transmitted by rodents and Tospoviruses by non- hematophagous thrips. Viruses within the Orthobunyavirus genus are generally transmitted by mosquitoes, whereas viruses in the Phlebovirus genus are vectored mainly by sand flies (Horne \& Vanlandingham, 2014).

Cockroaches are considered as efficient vectors of pathogens like bacteria, protozoa, fungi, eggs of pathogenic intestinal worms and viruses such as the Polio virus (Tatang et al., 2017). The poliomyelitis virus has been isolated from domiciliary species of cockroaches and the successful laboratory transmissions of a number of viral infections to cockroaches indicates their capability of acting as a vector to other viral diseases such as hepatitis (Tarshis, 1962).

\section{Insects and Covid-19}

The coronavirus is a RNA virus of the family Coronaviridae, genus Coronavirus (Miller, 1999), which was first isolated in 1937 (Dehghani \& Kassiri, 2020). As the largest known RNA viruses, coronaviruses are divided into four genera: alphacoronavirus, beta-coronavirus, gamma-coronavirus and delta-coronavirus. To date, there have been six human coronaviruses (HCoVs) identified, including severe acute respiratory syndrome-CoV (SARS-CoV) and Middle East respiratory syndrome-CoV (MERS-CoV) (Wu et al., 2020). New coronaviruses appear to emerge periodically in humans, mainly due to the high prevalence and wide distribution of coronaviruses, the large genetic diversity and frequent recombination of their genomes, and the increase of human-animal interface activities (Wu et al., 2020). The novel coronavirus reported in late December 2019, has now created a public health emergency of international concern and brought the world to a standstill. The novel coronavirus is the seventh member of the family coronaviruses, and is a betacoronavirus with over $70 \%$ similarity in genetic sequence to the SARS coronavirus. Bats are the most possible host of this pathogen, and snakes, minks and pangolins are also potential hosts (Wu et al., 2020).

The novel coronavirus is transmitted from person to person via respiratory droplets, close contact, aerosols, and possibly the faecal-oral route (Dehghani \& Kassiri, 2020). There have been no reports of COVID-19 transmission by bloodsucking arthropods such as mosquitoes or any other such insects (Dehghani \& Kassiri, 2020). However, viruses may be transmitted by arthropods in two ways, either biologically or mechanically. In mechanical transmission insects become contaminated with viruses during normal feeding behavior, and virus persists on their mouthparts or body until the next feed (Carn, 1996). 
Table 1: Viral diseases of humans transmitted by mosquitoes.

\begin{tabular}{|c|c|c|c|c|}
\hline Disease & $\begin{array}{l}\text { Family and Genus } \\
\text { of Virus }\end{array}$ & Affected Countries & Vector & Symptoms \\
\hline 1. Rift Valley Fever & $\begin{array}{l}\text { Bunyaviridae, } \\
\text { Phlebovirus (Tantely } \\
\text { et al., 2015) }\end{array}$ & $\begin{array}{l}\text { Several African countries and } \\
\text { the Arabian peninsula (Tantely } \\
\text { et al., 2015; Sang et al., 2017). } \\
\text { Outbreaks occur during periods } \\
\text { of heavy and persistent rainfall } \\
\text { that often leads to flooding } \\
\text { (Sang et al., 2017). }\end{array}$ & $\begin{array}{l}\text { Primary vectors are species of } \\
\text { genus Aedes, while secondary } \\
\text { vectors are of the genera Culex, } \\
\text { Anopheles, Mansonia (Arum et } \\
\text { al., 2015). }\end{array}$ & $\begin{array}{l}\text { Hemorrhagic fever, encephalitis, } \\
\text { mortality (Sang et al., 2017). }\end{array}$ \\
\hline 2. Zika Virus Infection & $\begin{array}{l}\text { Flavaviridae, } \\
\text { Flavivirus } \\
\text { (McKenzie et al., } \\
\text { 2019) }\end{array}$ & $\begin{array}{l}\text { The first large Zika Virus } \\
\text { outbreak occurred in 2007, in } \\
\text { Yap Island, Federated States of } \\
\text { Micronesia (McKenzie et al., } \\
\text { 2019). Another epidemic } \\
\text { occurred in } 2015 \text { in the } \\
\text { countries of the Americas } \\
\text { (Vorou, 2016). }\end{array}$ & $\begin{array}{l}\text { Principal vector is Aedes } \\
\text { aegypti. Aedes albopictus is also } \\
\text { established as a competent } \\
\text { vector. In Africa, Zika Virus is } \\
\text { transmitted by many species of } \\
\text { mosquitoes of the genus Aedes, } \\
\text { Ae. africanus, Ae. } \\
\text { apicoergenteus, Ae. opok, Ae. } \\
\text { dalzielli, Ae. furcifer, Anopheles } \\
\text { africanus, Anopheles coustani, } \\
\text { Anopheles gambiae, Mansonia } \\
\text { uniformis (Vorou, 2016). Aedes } \\
\text { henselli was implicated in the } \\
\text { Yap Island outbreak (McKenzie } \\
\text { et al., 2019). }\end{array}$ & $\begin{array}{l}\text { Macular or papular rash, fever, } \\
\text { arthritis or arthralgia, non-purulent } \\
\text { conjunctivitis, myalgia, headache, } \\
\text { retro-orbital pain, microcephaly in } \\
\text { fetuses born to mothers infected with } \\
\text { the disease (Vorou, 2016). }\end{array}$ \\
\hline 3. Yellow Fever & $\begin{array}{l}\text { Flaviviridae, } \\
\text { Flavivirus } \\
\text { (Waggoner et al., } \\
\text { 2018) }\end{array}$ & $\begin{array}{l}\text { Disease currently occurs in } \\
\text { Africa and Central and South } \\
\text { America (Barnett, 2007). } \\
\text { Recent outbreaks in Angola, } \\
\text { Democratic Republic of the } \\
\text { Congo and Brazil (McGuinness } \\
\text { et al., 2017). Historically large } \\
\text { outbreaks in Europe and North } \\
\text { America (Barnett, 2007). }\end{array}$ & $\begin{array}{l}\text { Mosquitoes of genus Aedes, } \\
\text { Haemogogus (McGuinness et } \\
\text { al., 2017). Aedes aegypti is the } \\
\text { main vector and other species } \\
\text { are Ae. africanus, Ae. opok, Ae. } \\
\text { simpsoni, Ae. luteocephalus, Ae. } \\
\text { taylori, Ae. vittatus (Ngoagouni } \\
\text { et al., 2012). Aedes bromeliae } \\
\text { (Agha et al., 2017). }\end{array}$ & $\begin{array}{l}\text { Fever, chills, headache, low back } \\
\text { pain, myalgia, nausea, vomiting, } \\
\text { fatigue. In severe cases high fever, } \\
\text { bleeding diatheses, abdominal pain, } \\
\text { renal failure, cardiovascular } \\
\text { instability, jaundice (McGuinness et } \\
\text { al., 2017). }\end{array}$ \\
\hline
\end{tabular}




\begin{tabular}{|c|c|c|c|c|}
\hline Disease & $\begin{array}{l}\text { Family and Genus } \\
\text { of Virus }\end{array}$ & Affected Countries & Vector & Symptoms \\
\hline $\begin{array}{l}\text { 4. West Nile Virus } \\
\text { Infection }\end{array}$ & $\begin{array}{l}\text { Flaviviridae, } \\
\text { Flavivirus (Petersen } \\
\text { et al., 2013) }\end{array}$ & $\begin{array}{l}\text { Western United States, North } \\
\text { America (Colpitts et al., 2012). } \\
\text { Africa, the Middle East, } \\
\text { Southern Europe, Western } \\
\text { Russia, South-Western Asia, } \\
\text { Australia (Petersen et al., } \\
\text { 2013). }\end{array}$ & $\begin{array}{l}\text { Mosquitoes of genus Culex are } \\
\text { the primary vectors: Culex } \\
\text { tarsalis, C. quinquefasciatus, C. } \\
\text { stigmatosoma, C. thriambus, C. } \\
\text { pipiens, C. nigripalpus (Colpitts } \\
\text { et al., 2012). Culex } \\
\text { tritaeniorhynchus, C. } \\
\text { antennatus, C. univittatus, C. } \\
\text { theileri, C. neavei. Certain } \\
\text { species of genus Aedes have also } \\
\text { been reported in transmitting the } \\
\text { disease: Aedes caballus, Ae. } \\
\text { circumluteolus, Ae. } \\
\text { albocephalus (Sule et al., 2018). } \\
\text { Anopheles species (Johnston \& } \\
\text { Conly, 2000). }\end{array}$ & $\begin{array}{l}\text { Fever, headache, neck stiffness, } \\
\text { vomiting, chills, confusion, ataxia } \\
\text { (Johnston \& Conly, 2000). In severe } \\
\text { cases neuroinvasive disease, } \\
\text { including encephalitis (Colpitts et al., } \\
\text { 2012). }\end{array}$ \\
\hline $\begin{array}{l}\text { 5. Japanese } \\
\text { encephalitis }\end{array}$ & $\begin{array}{l}\text { Flaviviridae, } \\
\text { Flavivirus (Solomon } \\
\text { et al., 2003) }\end{array}$ & $\begin{array}{l}\text { Eastern and Southern Asia } \\
\text { (Ghosh \& Basu, 2009). }\end{array}$ & $\begin{array}{l}\text { Transmitted principally by Culex } \\
\text { tritaeniorhynchus (Solomon et } \\
\text { al., 2003; Chen et al., 2019). } \\
\text { Two species of Culex spp., one } \\
\text { Anopheles sp., one Aedes sp., } \\
\text { one Armigeres sp. (Chen et al., } \\
\text { 2019). }\end{array}$ & $\begin{array}{l}\text { The disease mostly affects children. } \\
\text { The nervous system is affected } \\
\text { causing nonspecific fibrile illness, } \\
\text { diarrhea and rigor, reduced levels of } \\
\text { consciousness, seizures, headaches, } \\
\text { photophobia, vomiting (Ghosh \& } \\
\text { Basu, 2009). }\end{array}$ \\
\hline $\begin{array}{l}\text { 6. Dengue virus } \\
\text { infections }\end{array}$ & $\begin{array}{l}\text { Flaviviridae, } \\
\text { Flavivirus (Back \& } \\
\text { Lundkvist., 2013) }\end{array}$ & $\begin{array}{l}\text { Epidemics have occurred in } \\
\text { many countries. The first } \\
\text { epidemic occurred in } 1954 \text { in } \\
\text { Southeast Asia. Epidemics in } \\
\text { America: Cuba (1977-78, } \\
\text { 1997), Venezuela (1989), Latin } \\
\text { American countries. Africa } \\
\text { (Malavige et al., 2004). }\end{array}$ & $\begin{array}{l}\text { Species of genus Aedes: Aedes } \\
\text { aegypti is the primary vector, but } \\
\text { Ae. albopictus and Ae. } \\
\text { polynesiensis may also act as } \\
\text { vectors (Malavige et al., 2004). }\end{array}$ & $\begin{array}{l}\text { The dengue virus may cause dengue } \\
\text { fever or dengue hemorrhagic fever. } \\
\text { Dengue fever is characterized by } \\
\text { headache, retro-orbital pain, myalgia/ } \\
\text { arthralgia, maculopapular rash, } \\
\text { petechiae. Dengue hemorrhagic fever } \\
\text { results in mucosal bleeding, } \\
\text { hematemesis, easy bruising and } \\
\text { bleeding at venipuncture sites } \\
\text { (Singhi et al., 2007). }\end{array}$ \\
\hline
\end{tabular}




\begin{tabular}{|c|c|c|c|c|}
\hline Disease & $\begin{array}{l}\text { Family and Genus } \\
\text { of Virus }\end{array}$ & Affected Countries & Vector & Symptoms \\
\hline 7. Chikungunya Fever & $\begin{array}{l}\text { Togaviridae, } \\
\text { Alphavirus (Deeba et } \\
\text { al., 2016). }\end{array}$ & $\begin{array}{l}\text { Has caused outbreaks in the } \\
\text { countries of the Indian ocean } \\
\text { region, Africa and America } \\
\text { (Deeba et al., 2016). }\end{array}$ & $\begin{array}{l}\text { Transmitted by mosquitoes of } \\
\text { the genus Aedes. Aedes aegypti } \\
\text { is the most important vector and } \\
\text { has extensive worldwide } \\
\text { distribution. Aedes albopictus is } \\
\text { reported from Southeast Asia, } \\
\text { several European countries and } \\
\text { some Asian countries; it is } \\
\text { poorly distributed in the African } \\
\text { continent (Monteiro et al., } \\
\text { 2019). }\end{array}$ & $\begin{array}{l}\text { High fever, rashes, nausea, arthralgia } \\
\text { and myalgia (Deeba et al., 2016). }\end{array}$ \\
\hline $\begin{array}{l}\text { 8. Pogosta Disease } \\
\text { (Finland), Ockelbo } \\
\text { Disease (Sweden), } \\
\text { Karelian Fever } \\
\text { (Russia) }\end{array}$ & $\begin{array}{l}\text { Togaviridae, } \\
\text { Alphavirus (Sindbis } \\
\text { virus) (Kurkela et al., } \\
\text { 2004). }\end{array}$ & $\begin{array}{l}\text { Finland, Sweden, Russia } \\
\text { (Kurkela et al., 2004). Europe, } \\
\text { Africa, Asia, Australia (Laine } \\
\text { et al., 2004). }\end{array}$ & $\begin{array}{l}\text { Mosquitoes of genus Culex and } \\
\text { Culiseta (Kurkela et al., 2004). }\end{array}$ & $\begin{array}{l}\text { Arthritis, maculopapular rash, low } \\
\text { fever, fatigue, muscle pain (Kurkela } \\
\text { et al., 2004). The main clinical } \\
\text { symptoms are related to joints, and } \\
\text { are swelling and tenderness of the } \\
\text { ankle, knee, wrist or fingers, } \\
\text { especially the metacarpophalangeal } \\
\text { joints (Turunen et al., 1998). }\end{array}$ \\
\hline $\begin{array}{l}\text { 9. Mayaro Fever/ The } \\
\text { Jungle Flu }\end{array}$ & $\begin{array}{l}\text { Togaviridae, } \\
\text { Alphavirus (Izurieta } \\
\text { et al., 2018). }\end{array}$ & $\begin{array}{l}\text { Central and South America, } \\
\text { Caribbean (Izurieta et al., } \\
\text { 2018). }\end{array}$ & $\begin{array}{l}\text { Haemagogus janthinomys, Aedes } \\
\text { aegypti, Aedes scapularis, } \\
\text { Anopheles quadrimaculatus } \\
\text { (Izurieta et al. 2018). } \\
\text { Mosquitoes of genus Culex, } \\
\text { Mansonia, Psorophora, } \\
\text { Sabethes and Aedes albopictus } \\
\text { (Acosta-Ampudia et al., 2018). }\end{array}$ & $\begin{array}{l}\text { Fever, chills, persistent arthralgia, } \\
\text { retro-orbital pain, maculopapular } \\
\text { rash, itching, dizziness and rarely } \\
\text { lymphadenopathy (Izurieta et al., } \\
\text { 2018). As the most common } \\
\text { symptoms a triad is described as } \\
\text { abrupt fever, arthralgia/ arthritis, } \\
\text { maculopapular rash often related to } \\
\text { bleeding (Acosta-Ampudia et al., } \\
\text { 2018). }\end{array}$ \\
\hline $\begin{array}{l}\text { 10. Barmah Forest } \\
\text { Virus Disease }\end{array}$ & $\begin{array}{l}\text { Togaviridae, } \\
\text { Alphavirus (Caly et } \\
\text { al., 2019). }\end{array}$ & $\begin{array}{l}\text { Australia (Ehlkes et al., 2012). } \\
\text { Papua New Guinea (Caly et al., } \\
\text { 2019). }\end{array}$ & $\begin{array}{l}\text { Aedes vigilax, Ae. procax, Ae. } \\
\text { camptorhynchus, Ae. } \\
\text { notoscriptus, Verrallina funerea, }\end{array}$ & $\begin{array}{l}\text { Rash, fever, arthralgia, myalgia, } \\
\text { lethargy (Ehlkes et al., 2012). }\end{array}$ \\
\hline
\end{tabular}




\begin{tabular}{|c|c|c|c|c|}
\hline Disease & $\begin{array}{l}\text { Family and Genus } \\
\text { of Virus }\end{array}$ & Affected Countries & Vector & Symptoms \\
\hline $\begin{array}{l}\text { 11. Ross River Virus } \\
\text { Infection }\end{array}$ & $\begin{array}{l}\text { Togaviridae, } \\
\text { Alphavirus (Harley et } \\
\text { al., 2001). }\end{array}$ & $\begin{array}{l}\text { Australia, Papua New Guinea, } \\
\text { Fiji, New Caledonia, Samoa, } \\
\text { the Cook Islands (Harley et al., } \\
\text { 2001). }\end{array}$ & $\begin{array}{l}\text { Culex annulirostris, } \\
\text { Coquillettidia linealis (Ehlkes et } \\
\text { al., 2012). } \\
\text { Aedes vigilax, Ae. } \\
\text { camptorhynchus, Culex } \\
\text { annulirostris (Harley et al., } \\
\text { 2001). }\end{array}$ & $\begin{array}{l}\text { Joint manifestations ranging from } \\
\text { tenderness, extreme redness, swelling } \\
\text { and with effusions. Ankles, fingers, } \\
\text { wrists and knees are the joints most } \\
\text { commonly affected. Rashes may } \\
\text { appear mainly on the limbs and } \\
\text { trunk, but may also occur on the } \\
\text { palms, soles, digits, face and scalp. } \\
\text { Fever, arthralgia, } \\
\text { myalgia,splenomegaly, hematuria, } \\
\text { glomerulonephritis (Harley et al., } \\
\text { 2001). }\end{array}$ \\
\hline
\end{tabular}


Table 2: Insect vectors of human viral diseases (with the exception of mosquitoes).

\begin{tabular}{|c|c|c|c|c|}
\hline Disease & $\begin{array}{l}\text { Family and Genus } \\
\text { of Virus }\end{array}$ & Affected Countries & Vector & Symptoms \\
\hline Sand fly Fever & $\begin{array}{l}\text { Bunyaviridae, } \\
\text { Phlebovirus (Brett- } \\
\text { Major \& Claborn, } \\
\text { 2009). }\end{array}$ & $\begin{array}{l}\text { Southern Europe (Brett-Major } \\
\text { \& Claborn, 2009). In 1937, a } \\
\text { massive outbreak occurred in } \\
\text { Athens, Greece. Several } \\
\text { outbreaks in the Middle East, } \\
\text { the Mediterranean and North } \\
\text { Africa (Ayhan \& Charrel, } \\
\text { 2018). }\end{array}$ & $\begin{array}{l}\text { Sandflies (Diptera, Psychodidae) } \\
\text { (Brett-Major \& Claborn, 2009). } \\
\text { Phlebotomus papatasi (Ayhan \& } \\
\text { Charrel, 2018). }\end{array}$ & $\begin{array}{l}\text { Headache, photophobia, retro-orbital } \\
\text { pain, anorexia, myalgia, low back } \\
\text { pain (Brett-Major \& Claborn, 2009). }\end{array}$ \\
\hline $\begin{array}{l}\text { Toscana Virus } \\
\text { Infection }\end{array}$ & $\begin{array}{l}\text { Bunyaviridae, } \\
\text { Phlebovirus (Howell } \\
\text { et al., 2015). }\end{array}$ & $\begin{array}{l}\text { European Mediterranean } \\
\text { countries from Spain to Turkey, } \\
\text { the North African countries of } \\
\text { Tunisia and Morocco (Howell } \\
\text { et al., 2015). }\end{array}$ & $\begin{array}{l}\text { Phlebotomus perniciosus, } P \text {. } \\
\text { perfiliewi (Howell et al., 2015). } \\
\text { Phlebotomus longicuspis, } P \text {. } \\
\text { sergenti, P. neglectus, } \\
\text { Sergentomyia minuta (Ayhan \& } \\
\text { Charrel, 2018). }\end{array}$ & $\begin{array}{l}\text { Headache, fever, nausea vomiting, } \\
\text { myalgia (Howell et al., 2015). } \\
\text { Meningitis, encephalitis (Ayhan \& } \\
\text { Charrel, 2018). }\end{array}$ \\
\hline Adria Virus Infection & $\begin{array}{l}\text { Bunyaviridae, } \\
\text { Phlebovirus } \\
\text { (Anagnostou et al. } \\
\text { 2011). }\end{array}$ & $\begin{array}{l}\text { Greece (Anagnostou et al. } \\
\text { 2011). }\end{array}$ & $\begin{array}{l}\text { Phlebotomus species } \\
\text { (Anagnostou et al., 2011) }\end{array}$ & $\begin{array}{l}\text { Febrile seizure, perioral cyanosis, } \\
\text { masseter muscle spasm, generalized } \\
\text { tonic convulsions of the body and } \\
\text { extremities, involuntary loss of urine } \\
\text { (Anagnostou et al., 2011). }\end{array}$ \\
\hline
\end{tabular}


Insects such as cockroaches and houseflies, which are major mechanical vectors of pathogens, can transmit diseases by contact with contaminated surfaces and studies have associated insects such as beetles and domestic insects as mechanical carriers of pathogens (Dehghani \& Kassiri, 2020). SARScoronavirus, MERS-coronavirus and influenza virus can survive on surfaces for extended periods, sometimes upto months, depending on the strain variation, titre, surface type, suspending medium, mode of deposition, temperature and relative humidity of the environment (Otter et al., 2016). COVID-19 virus mainly occurs in respiratory samples of infected persons but have been reported in feces samples in a limited number of cases (Dehghani \& Kassiri, 2020). According to Eslami \& Jalili (2020), SARS-CoV-2 excretion by stool has been confirmed in some patients. Nath and Gupta (2020) reveals that the virus can be found in a person's stool and can remain viable for days in favourable atmospheric conditions. Therefore, any organism in contact with or feeding on human feces may play a role in COVID-19 transmission, and thus the role of insects such as houseflies and cockroaches becomes important. These insects are capable of transmitting more than 100 pathogens through their legs, body hair, mouthparts, feces and vomit which may occur on human food waste, sputum, nasal secretions, fresh and dried blood and stool (Dehghani \& Kassiri, 2020).

Currently insects are known to transmit viruses of families Flaviviridae, Togaviridae and Bunyaviridae, and insect transmission of viruses of family Coronaviridae has not been documented. Further, when considering the deadly pandemics recorded in history, pandemics caused by viruses are few and when viruses are the pathogens, transmission is usually air-borne. Smallpox that has now been eradicated from the world was caused by the variola virus and transmitted by the air-borne respiratory route (MacIntyre et al., 2020).

Therefore, the biological transmission of COVID19 by insects may not be a possible route for the disease to spread. However, the mechanical transmission of the virus by insects other than mosquitoes cannot be entirely ruled out. The new coronavirus was detected in the feces of confirmed patients in Wuhan, Shenzhen and the United States, indicating that the virus can exist and replicate in the digestive tract. However, it is not certain that eating virus-contaminated food causes infection and transmission (Wu et al., 2020). The mode of infection transmission has profound implications for effective containment of diseases by public health interventions. Therefore, it is important that the methods of COVID-19 transmission be further examined and understood.

\section{Conclusions}

Insects are important vectors of human viral diseases. Amongst insects, mosquitoes are the prominent vectors causing biological transmission of diseases, and sandflies, houseflies and cockroaches can cause mechanical transmission. COVID-19 is a deadly infectious disease caused by the most recently discovered coronavirus. It is an ongoing pandemic spread by air when people are physically close. However, it may also be transmitted via contaminated surfaces, although this has not been conclusively demonstrated. Therefore, insects in contact with or feeding on contaminated surfaces may play a role in COVID19 transmission. At the moment the link is theoretical and under possible investigation. However, in the past insects and pandemics seem to be inextricably linked in a negative manner in the minds of people and thus their role in COVID19 transmission is compelled for attention.

\section{References}

Acosta-Ampudia, Y., Monsalve, D.M., Rodriguez, Y., Pacheco, Y., Anaya, J.M., Ramirez-Santana, C. (2018) Mayaro: an emerging viral threat? Emerging Microbes \& Infections 7: 163174.DOI:10.1038/s41426-018-0163-5

Agha, S.B., Tchouassi, D.P., Bastos, A.D.S., Sang, R. (2017) Dengue and yellow fever virus vectors: seasonal abundance, diversity and resting preferences in three Kenyan cities, Parasites \& Vectors 10: 628.DOI:10.1186/s13071-017-25982

Anagnostou, V., Pardalos, G., Athanasiou-Metaxa, M., Papa, A. (2011) Novel phlebovirus in febrile child, Greece, Emerging Infectious Diseases 17(5): 940-941.

Arum, S.O., Weldon, C.W., Orindi, B., Landmann, T., Tchouassi, D.P., Affognon, H.D., Sang, R. (2015) Distribution and diversity of the vectors of Rift Valley fever along the livestock movement routes in the northeastern and coastal regions of Kenya, Parasites \& Vectors 8: 294302.DOI 10.1186/s13071-015-0907-1

Ayhan, N., Charrel, R.N. (2018) Sandfly-borne viruses of demonstrated/ relevant medical importance. In: Vectors and vector-borne zoonotic diseases, IntechOpen, London, United Kingdom.

Back, A.T., Lundkvist, A. (2013) Dengue viruses an overview, Infection Ecology and Epidemiology 3:1.

Barnett, E.D. (2007) Yellow Fever: Epidemiology and prevention, Emerging Infections 44: 850856.DOI:10.1086/511869 
Brett-Major, D.M., Claborn, D.M. (2009) Sand fly fever: What have we learned in one hundred years ?, Military Medicine 174(4): 426-431.

Caly, L., Horwood, P.F., Vijaykrishna, D., Lynch, S., Greenhill, A.R., Pomat, W., Rai, G., Kisa, D., Bande, G., Druce, J., Abdad, M.Y. (2019) Divergent Barmah Forest virus from Papua New Guinea, Emerging Infectious Diseases 25(12): 2266-2269.

DOI: https://doi.org/10.3201/eid2512.191070

Carn, V.M. (1996) The role of dipterous insects in the mechanical transmission of animal viruses, British Veterinary Journal 152(4): $377-$ 393.https://doi.org/10.1016/S00071935(96)80033-9

Chen, R., Mukhopadhyay, S., Merits, A., Bolling, B., Nasar, F., Coffey, L.L., Powers, A., Weaver, S.C., ICTV Report Consortium. (2018) ICTV virus taxonomy profile: Togaviridae, Journal of General Virology 99: 761-762. DOI:10.1099/jgv.0.001072

Chen, C., Zhao, T., Jiang, Y., Li, C., Wang, G., Gao, J., Dong, Y., Xing, D., Guo, X., Zhao, T. (2019) Vector mosquito ecology and Japanese encephalitis virus genotype III strain detection from Culex tritaeniorhynchus and pig in Huaihua, China, Vector-Borne and Zoonotic Diseases 19(12): 933944.https://doi.org/10.1089/vbz.2019.2453

Cirillo, V.J. (2016) "I am the baby killer!" Houseflies and the spread of polio, American Entomologist 62(2): 83-85. DOI:10.1093/ae/tmw039

Colpitts, T.M., Conway, M.J., Montgomery, R.R., Fikrig, E. (2012) West Nile Virus: Biology, transmission, and human infection, Clinical Microbiology Reviews 25(4): 635648.DOI:10.1128/CMR.00045-12

Cook, M.T. (1937) Insect transmission of virus diseases of plants, The Scientific Monthly 44(2): 174-177.

Das, B., Ghosal, S., Mohanty, S. (2018) Aedes: What do we know about them and what can they transmit ? In: Vectors and vector-borne zoonotic diseases, IntechOpen, London, United Kingdom. DOI: http://dx.doi.org/10.5772/intechopen.81363

Deeba, F., Islam, A., Kazim, S.N., Naqvi, I.H., Broor, S., Ahmed, A., Parveen, S. (2016) Chikungunya virus: recent advances in epidemiology, host pathogen interaction and vaccine strategies, Pathogens and Disease 74: 110.doi: $10.1093 /$ femspd/ftv119

Dehghani, R., Kassiri, H. (2020) A brief review on the possible role of houseflies and cockroaches in the mechanical transmission of Coronavirus Disease 2019 (COVID-19), Archives of Clinical Infectious Diseases $15 . \quad$ doi: 10.5812/archcid.102863
Dutto, M., Bertero, M., Petrosillo, N., Pombi, M., Otranto, D. (2016) Ebola virus and arthropods: A literature review and entomological consideration on the vector role, Bulletin de la Societe de Pathologie Exotique 109: 244-247. DOI 10.1007/s13149-016-0525-y

Ehlkes, L., Eastwood, K., Webb, C., Durrheim, D. (2012) Surveillance should be strengthened to improve epidemiological understandings of mosquito-borne Barmah Forest virus infection, Western Pacific Surveillance and Response Journal 3(3): 63-68. doi:10.5365/wpsar.year.2012.3.1.004

Eslami, H., Jalili, M. (2020) The role of environmental factors to transmission of SARSCoV-2 (COVID-19), AMB Express 10(92): 1-8. https://doi.org/10.1186/s13568-020-01028-0

Ghosh, D., Basu, A. (2009) Japanese Encephalitis A pathological and clinical perspective, PLoS Neglected Tropical Diseases (9).doi:10.1371/journal.pntd.0000437

Greenberg, B. (1965) Flies and disease, Scientific American 213(1): 92-99.

Haddow, A.D., Nasar, F., Schellhase, C.W., Moon, R.D., Padilla, S.L., Zeng, X., Wollen-Roberts, S.E., Shamblin, J.D., Grimes, E.C., Zelko, J.M., Linthicum, K.J., Bavari, S., Pitt, M.L., Trefry, J.C. (2017) Low potential for mechanical transmission of Ebola virus via house flies (Musca domestica), Parasites \& Vectors 10: 218222. DOI 10.1186/s13071-017-2149-X

Harley, D., Sleigh, A., Ritchie, S. (2001) Ross river virus transmission, infection and disease: a crossdisciplinary review, Clinical Microbiology Reviews 14(4): 909-932. DOI:10.1128/CMR.14.4.909-932.2001

Horne, K.M., Vanlandingham, D.L. (2014) Bunyavirus-vector interactions, Viruses 6: 43734397.doi:10.3390/v6114373

Howell, B.A., Azar, M.M., Landry, M.L., Shaw, A.C. (2015) Toscana virus encephalitis in a traveler returning to the United States, Journal of Clinical Microbiology 53(4): 14451447.DOI:10.1128/JCM.03498-14

Huhtamo, E., Putkuri, N., Kurkela, S., Manni, T., Vaheri, A., Vapalahti, O., Uzcategui, N.Y. (2009) Characterization of a novel flavivirus from mosquitoes in Northern Europe that is related to mosquito-borne flaviviruses of the tropics, Journal of Virology 83(18): 95329540.doi:10.1128/JVI.00529-09

Izurieta, R.O., DeLacure, D.A., Izurieta, A., Hoare, I.A., Ortiz, M.R. (2018) Mayaro virus: the jungle flu, Virus Adaptation and Treatment 10: 9-17.

Johnston, L., Conly, J.M. (2000) West Nile virus Where did it go from and where might it go? Canadian Journal of Infectious Diseases and Medical Microbiology 11(4): 175-178. 
Khamesipour, F., Lankarani, K.B., Honarvar, B., Kwenti, T.E. (2018) A systematic review of human pathogens carried by the housefly (Musca domestica L.), BMC Public Health 18: 10491064. https://doi.org/10.1186/s12889-018-5934-3

Kurkela, S., Manni, T., Vaheri, A., Vapalahti, O. (2004) Causative agent of Pogosta Disease isolated from blood and skin lesions, Emerging Infectious Diseases 10(5): 889-894.

Laine, M., Luukkainen, R., Toivanen, A. (2004) Sindbis viruses and other alphaviruses as cause of human arthritic disease, Journal of Internal Medicine 256: 457-471.

Lindsay, D.R., Scudder, H.I. (1955) Nonbiting flies and disease, Annual Review of Entomology 1: 323-346.

Ludwig, G.V., Iacono-Connors, L.C. (1993) Insecttransmitted viruses: Flaviviridae, In Vitro Cellular \& Developmental Biology 29A: 296309.

MacGregor, M.E. (1918) Insects as carriers of disease, Transactions of the American Microscopical Society 37(1): 7-17.

MacIntyre, C.R., Das, A., Chen, X., De Silva, C., Doolan, C. (2020) Evidence of long-distance aerial convection of variola virus and implications for disease control, Viruses 12(33): 1-19.doi:10.3390/v12010033

Malavige, G.N., Fernando, S., Fernando, D.J., Seneviratne, S.L. (2004) Dengue viral infections, Postgraduate Medical Journal 80: 588-601. doi:10.1136/pgmj.2004.019638

McKenzie, B.A., Wilson, A.E., Zohdy, S. (2019) Aedes albopictus is a competent vector of Zika virus: A meta-analysis, PLoS ONE 14(5): 116.https://doi.org/10.1371/journal.pone.0216794

McGuinness, I., Beckham, J.D., Tyler, K.L., Pastula, D.M. (2017) An overview of yellow fever virus disease, The Neurohospitalist 7(4): 157-158.DOI:10.1177/1941874417708129

Miller, M.J. (1999) Viral taxonomy, Clinical Infectious Diseases 29: 731-733.

Monteiro, V.V.S., Navegantes-Lima, K.C., de Lemos, A.B., da Silva, G.L., Gomes, R.deS., Reis, J.F., Rodrigues Junior, L.C., da Silva, O.S., Romao, P.R.T., Monteiro, M.C. (2019) AedesChikungunya virus interaction: Key role of vector midguts microbiota and its saliva in the host infection, Frontiers in Microbiology 10: 492-504.

doi:10.3389/fmicb.2019.00492

Nath, T.M., Gupta, B. (2020) Novel coronavirus disease-2019 (COVID-19): A review, European Journal of Pharmaceutical and Medical Research 7(5): 648-653.

Ngoagouni, C., Kamgang, B., Manirakiza, A., Nangouma, A., Paupy, C., Nakoune, E., Kazanji, M. (2012) Entomological profile of yellow fever epidemics in the Central African Republic, 20062010, Parasites \& Vectors 5:175. http://www.parasitesandvectors.com/content/5/1/ 175

Otter, J.A., Donskey, C., Yezli, S., Douthwaite, S., Goldenberg, S.D., Weber, D.J. (2016) Transmission of SARS and MERS coronaviruses and influenza virus in healthcare settings: the possible role of dry surface contamination, Journal of Hospital Infection 92: 235250.http://dx.doi.org/10.1016/j.jhin.2015.08.027

Petersen, L.R., Brault, A.C., Nasci, R.S. (2013) West Nile Virus: Review of the literature, JAMA 310(3): 308-315.doi:10.1001/jama.2013.8042

Powell, J.R. (2018) Mosquito-borne human viral diseases: Why Aedes aegypti ?, The American Journal of Tropical Medicine and Hygiene 98(6): 1563-1565.doi:10.4269/ajtmh.17-0866

Salas-Benito, J.S., De Nova Ocampo, M. (2015) Viral interference and persistence in mosquitoborne flaviviruses, Journal of Immunology Research 1-14. http://dx.doi.org/10.1155/2015/873404

Sang, R., Arum, S., Chepkorir, E., Mosomtai, G., Tigoi, C., Sigei, F., Lwande, O.W., Landmann, T., Affognon, H., Ahim, C., Evander, M. (2017) Distribution and abundance of key factors of Rift Valley fever and other arboviruses in two ecologically distinct countries in Kenya, PLoS Neglected Tropical Diseases 11 (2): 112.doi:10.1371/journal.pntd.0005341

Sarwar, M. (2016) Mosquito-borne viral infections and diseases among persons and interfering with the vector activities, International Journal of Vaccines and Vaccination 3(2): 00063.

Singhi, S., Kissoon, N., Bansal, A. (2007) Dengue and dengue hemorrhagic fever: management issues in an intensive care unit, Jornal de Pediatria 83(2): 22-35.doi:10.2223/JPED.1622

Solomon, T., Ni, H., Beasley, D.W.C., Ekkelenkamp, M., Cardosa, M.J., Barrett, A.D.T. (2003) Origin and evolution of Japanese Encephalitis virus in Southeast Asia, Journal of Virology 77(5): 30913098.DOI:10.1128/JVI.77.5.3091-3098.2003

Sule, W.F., Oluwayelu, D.O., Hernandez-Triana, L.M., Fooks, A.R., Venter, M., Johnson, N. (2018) Epidemiology and ecology of West Nile virus in sub-Saharan Africa, Parasites \& Vectors 11: 414 . https://doi.org/10.1186/s13071-0182998-y

Tantely, L.M., Boyer, S., Fontenille, D. (2015) Review article: A review of mosquitoes associated with Rift Valley Fever Virus in Madagascar, American Journal of Tropical Medicine and Hygiene 92(4): 722729.doi:10.4269/ajtmh.14-0421 
Tarshis, I.B. (1962) The cockroach - A new suspect in the spread of infectious hepatitis, The American Society of Tropical Medicine and Hygiene 11(5): 705-711. https://doi.org/10.4269/ajtmh.1962.11.705

Tatang, R.J.A., Tsila, H.G., Pone, J.W. (2017) Medically important parasites carried by cockroaches in Melong Subdivision, Littoral, Cameroon, Journal of Parasitology Research 18.https://doi.org/10.1155/2017/7967325

Turunen, M., Kuusisto, P., Uggeldahl, P.E., Toivanen, A. (1998) Pogosta Disease: Clinical observations during an outbreak in the province of North Karelia, Finland, British Journal of Rheumatology 37(1): 1177-1180.

Vorou, R. (2016) Zika virus, vectors, reservoirs, amplifying hosts, and their potential to spread worldwide: what we know and what we should investigate urgently, International Journal of Infectious Diseases 48: 85-90. http://dx.doi.org/10.1016/j.ijid.2016.05.014

Waggoner, J.J., Rojas, A., Pinsky, B.A. (2018) Yellow fever virus: Diagnostics for a persistent arboviral threat, Journal of Clinical Microbiology 56(10): 1-13. https://doi.org/10.1128/JCM.00827-18

Weissenbock, H., Hubalek, Z., Bakonyi, T., Nowotny, N. (2010) Zoonotic mosquito-borne flaviviruses: Worldwide presence of agents with proven pathogenicity and potential candidates of future emerging diseases, Veterinary Microbiology 140: 271-280. doi:10.1016/j.vetmic.2009.08.025

Wu, D., Wu, T., Liu, Q., Yang, Z. (2020) The SARS-CoV-2 outbreak: What we know, International Journal of Infectious Diseases 94: 44-48. https://doi.org/10.1016/j.ijid.2020.03.004 